\title{
Perubahan Makna serta Benturan Klaim akan Ruang Kota pada Kawasan Taman Kencana Bogor
}

\author{
Karya Widyawati ${ }^{1}$ dan Nia Suryani ${ }^{2}$ \\ ${ }^{1}$ Universitas Indraprasta PGRI \\ ${ }^{2}$ Universitas Indraprasta PGRI \\ widyawatik@yahoo.co.id
}

\begin{abstract}
ABSTRAK
Taman Kencana Bogor menjadi saksi perkembangan Kota Bogor dari masa penjajahan dulu sebagai sebuah kawasan permukiman bagi para peneliti dan pegawai pemerintahan. Sejak berkembangnya Bogor, kawasan ini sudah mengalami perubahan drastis. Pemanfaatan bangunan sebagai sebuah tempat usaha telah merubah banyak struktur ruang kota. Selain itu semakin terkenalnya Taman Kencana sebagai sebuah titik wisata kuliner di Bogor memberikan dampak juga terhadap tempat ini. Untuk mengungkap dampak perkembangan kawasan ini, dilakukan dengan pengumpulan data kualitatif, riset arsip, serta wawancara dan pengamatan secara berkala. Keadaan ini pun mengindikasikan adanya hubungan tarikmenarik kepentingan antara fungsi kawasan sebagai kawasan permukiman dan kawasan wisata kuliner, dan terjadilah benturan klaim akan ruang.
\end{abstract}

Kata kunci: klaim, perkembangan kawasan, permukiman, kualitas lingkungan

\begin{abstract}
Taman Kencana Bogor be a witness of the development of the city of Bogor from the colonial period as a residential area for researchers and government employees. Since the development of Bogor this area has drastic changes. Utilization of buildings as a place of business has changed the structure of many urban space. In addition, the more famous Taman Kencana as a culinary tourist point in Bogor also gives impact to this place. To reveal the impact of the development of this region, conducted with qualitative data collection, archival research, and interviews and observations on a regular basis. This situation also indicates a relationship of attraction between the interests of the function area as a residential area and culinary tourism, and there was a clash of claims to space
\end{abstract}

Keywords: claims, regional developments, settlements, environmental quality

\section{Pendahuluan}

Taman Kencana menjadi saksi perkembangan Kota Bogor dari masa penjajahan dulu. Menurut beberapa arsip sejarah, Taman Kencana pada awalnya dikenal sebagai Van Imhoff Plein alias Van Imhoff Square. Pembangunan taman ini dilakukan bersamaan dengan pengembangan Kota Bogor atau dikenal sebagai Buitenzorg pada masa itu yang dimulai perencanaannya tahun 1917. Proses pengembangan Bogor di masa tersebut bermula dari meningkatnya jumlah penduduk baik pribumi maupun dari kalangan penduduk Eropa. Di tahun 1904, Buitenzorg ditetapkan sebagai sebuah kawasan dengan luas 1,205 hektar dan proyeksi penghuninya adalah 30,000 jiwa. Proyeksi ini tercantum dalam Keputusan Gubernur Jendral Van Nederland Indie no 4 tahun 1904. Berdasarkan proyeksi inilah sebuah rencana pengembangan pemukiman bagi bangsa Eropa dibuat dan pilihan jatuh untuk mengembangkan wilayah Timur dari Buitenzorg di seberang Ciliwung. Wilayah tersebut dikenal sebagai Kedoeng 
Halang di masa itu. Area ini mencakup kawasan yang sekarang menjadi Taman Kencana dan sekitarnya.

Untuk mematangkan rencana pengembangan pemukiman Pemerintah Kolonial Belanda menunjuk Ir. Thomas Karsten tahun 1917. Karsten sendiri adalah seorang insinyur Belanda yang juga melakukan perencanaan serupa terhadap kota Semarang (1916) dan Malang (1931). Dalam rencananya Karsten mentargetkan akan ada 400 rumah tinggal bagi warga Eropa dari berbagai profesi seperti peneliti pegawai pemerintahan dan lain-lain. Selain rumah tinggal, kawasan Taman Kencana memang ditargetkan untuk beberapa gedung pemerintahan, salah satunya adalah Balai Penelitian Perkebunan. Berbagai bangunan di kawasan Taman Kencana ini dibuat dengan desain yang dikembangkan oleh Karsten.

Bentukan rumah-rumah di kawasan ini disebut Indo-Eropa yang merupakan perpaduan gaya arsitektur di Eropa yang telah disesuaikan dengan kondisi dan lingkungan tropis di Indonesia. Kawasan permukiman Indo-Eropa ini hadir sebagai sebuah district yakni suatu kawasan yang memiliki karakter khusus dan memiliki batas terhadap kawasan lain. Karakter district ini dimaknai sebagai salah satu aset peninggalan masa kolonial yang memiliki tatanan lansekap kawasan yang pernah diduduki oleh kaum penjajah. Permukiman ini diperuntukkan sebagai rumah dinas bangsa Eropa sesuai strata sosialnya, meliputi pegawai, peneliti, militer dan penguasa yang bekerja di kantor-kantor pemerintahan di sekitarnya pada masa itu.

Kawasan ini terbagi menjadi tiga zona yakni zona I merupakan kawasan permukiman yang diperuntukan bagi kelas militer dan pegawai, sedangkan zona II dan zona III untuk strata sosial yang lebih tinggi yakni peneliti, petinggi, atau penguasa. Bentuk bangunan di kawasan Taman Kencana ini dibuat dengan desain yang dikembangkan oleh Karsten. Bentuknya disebut Indo-Eropa yang merupakan perpaduan gaya arsitektur di Eropa yang telah disesuaikan dengan kondisi lingkungan tropis di Indonesia. Bangunan di kawasan ini memiliki ciri berupa kemiringan atap 35 derajat. Tujuannya adalah untuk mengantisipasi curah hujan yang tinggi di Bogor. Selain itu bentuk jendela yang lebar dan adanya lubang angin dibuat untuk menghadapi teriknya matahari tropis di kala musim kemarau. Lebarnya jendela dan adanya lubang angin akan membantu sirkulasi angin di dalam rumah. Kawasan permukiman ini dirancang sebagai tempat bertinggal serta beristirahat, tak heran jalan-jalan pun dibuat lebar dan rindang sehingga menjadi sejuk dan tenang. Setiap rumah memiliki halaman yang luas.

Meskipun demikian, sejak berkembangnya Bogor, kawasan ini sudah mengalami perubahan drastis. Pemanfaatan bangunan sebagai sebuah tempat usaha telah merubah banyak struktur ruang kota. Selain itu semakin terkenalnya Taman Kencana sebagai sebuah titik wisata kuliner di Bogor memberikan dampak juga terhadap tempat ini. Berbagai bangunan semi permanen maupun permanen berdiri dengan tidak menyesuaikan dengan konsep awal berupa Garden City di kawasan ini.

Kawasan Taman Kencana kini hadir dengan suguhan suasana taman yang belum lama ini telah dibenahi oleh Pemerintah Kota Bogor sehingga kualitas lingkungan sudah jauh lebih baik. Di kawasan ini banyak terdapat jajanan kuliner yang telah ada sejak puluhan tahun lalu dan selalu merindukan untuk disambangi sekedar untuk nostalgia dengan rasa dan suasananya. Kawasan Taman Kencana makin banyak pengunjungnya apalagi pada saat akhir pekan. Hampir setiap jalan di sekitar kawasan Taman Kencana ramai dilalui kendaraan, baik motor maupun mobil yang kebanyakan berasal dari luar kawasan ini. Dari pukul 6 pagi hingga malam hari, kawasan ini makin ramai pengunjung, bahkan banyak mobil dengan plat nomor luar Bogor yang terlihat melintas di jalan-jalan sekitar kawasan ini. Kawasan Taman Kencana tak lagi setenang dulu, kini berubah menjadi salah satu pusat pergerakan ekonomi kreatif di Bogor. Lalu dengan terjadinya fenomena tersebut, Perubahan apa yang terjadi atas dampak perkembangan Kawasan Taman Kencana? 


\section{Bahan dan Metode \\ 2.1 Bahan Kajian Teori \\ 2.1.1 Makna Ruang}

Menurut Lao Tzu ruang adalah "kekosongan" yang ada di sekitar kita maupun di sekitar objek atau benda. Ruang yang ada di dalamnya lebih hakiki dibanding materialnya atau massanya. Ruang tidak dapat dipisahkan dari kehidupan manusia, baik secara psikologi, emosional, dan dimensional. Manusia berada dalam ruang, bergerak, menghayati, berpikir dan juga menciptakan dan menyatakan bentuk dunianya dalam mencapai kesejahteraan hidup. Kesejahteraan hidup yang berkaitan dengan kondisi manusia menuntut tersedianya ruang agar kelangsungan seluruh tahap daur hidup manusia sejak dalam kandungan, lahir hingga kematian terwadahi dengan baik, (Arendt, 1958).

Pada dasarnya ruang dalam hal yang dibahas tidak selalu mengacu pada suatu yang nyata melainkan lebih ke batas-batas maya. Ruang tidak hanya dapat dirasakan dengan batas-batas yang bersifat masif misalkan dinding pembatas dan pintu tapi juga oleh elemen-elemen pembentuk ruang yang tidak masif seperti perbedaan ketinggian lantai, warna, dan cahaya.

Yi Fu Tuan dalam Space and Place, The Perspective of Experience memaparkan ruang merupakan sesuatu yang abstrak, yang hadir dalam mental pikir manusia yang hanya bisa dirasakan secara kualitas seiring manusia bergerak di dalamnya. Namun ruang juga hadir secara visual dalam wujud fisiknya melalui cerapan indrawi manusia. Mental pikir manusia tak selalu memaknai ruang sesuai dengan fungsinya.

Pemaknaan atau pernyataan tentang ruang di kepala manusia bisa dilihat sebagai sebuah klaim. Klaim dilihat sebagai suatu pernyataan dengan motivasi hasrat serta perasaan memiliki akan sesuatu. Hasrat tersebut mendorong manusia merasa berhak akan apa yang ada di dalam mental pikirnya demi memenuhi kebutuhan untuk mencapai kesejahteraan hidup.

Sebenarnya kata klaim diadaptasi dari bahasa Inggris claim yang berasal dari bahasa Prancis kuno claimer dan bahasa Latin clamare yang berarti menyebut atau menyatakan. Dalam prakteknya tindakan klaim sering diiringi dengan argumen dan hak dan bisa berlaku dalam ruang (Bishay, 2004). Klaim bisa bernilai positif atau negatif. Saat klaim dilakukan tanpa mengganggu hak orang lain, klaim tersebut adalah klaim positif. Namun saat klaim dilakukan dengan mengganggu hak orang lain, klaim tersebut adalah negatif. Klaim berhubungan dengan teritori. Klaim menghasilkan teritori yakni suatu ruang yang dibatasi dan dipertahankan orang lain (Maya Sita 2010).

Bill Hillier (2007) menyatakan klaim biasanya dilakukan dengan menetapkan batas dan dilanjutkan dengan pemberian identitas secara sepihak. Saat kita sudah membuat suatu batas dalam sebuah ruang seolah menamainya dengan suatu kategori. Nama tersebut merupakan indikasi dari kategori ruang yang dibatasi batas tersebut namun secara tersirat juga memberikan kategori untuk ruang di luar batasan itu. Tanpa sadar kita telah mengungkap ada perbedaan teritori antara inside dan outside. Peneliti mencoba menggambarkan hal tersebut pada diagram Venn saat menjelaskan tentang teori himpunan dalam ilmu matematika agar jelas terlihat perbedaannya.

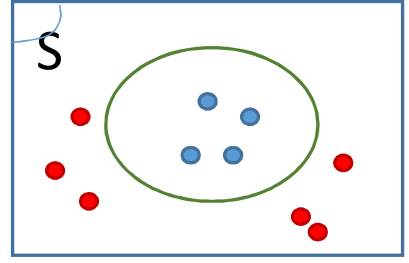

Gambar 1. Diagram Venn dalam tindakan klaim terhadap ruang 
Hubungan ruang-ruang yang dibentuk oleh lingkaran yang dapat dianalogikan dalam penghadiran batas dalam kehidupan nyata. Dalam diagram Venn di samping, proses pemberian batas dan kategori dilakukan oleh lingkaran oranye yang ada di dalam kotak persegi panjang. Batas lingkaran tersebut seolah memberikan kategori bahwa hal atau benda yang ada di dalam lingkaran tersebut adalah teritorinya dan dicerna dalam mental pikirnya sebagai area inside. Dan secara tidak langsung hal-hal yang ada di luar lingkaran bukan jangkauan atau teritorinya sehingga dimaknai sebagai area outside namun kedua area tetap ada dalam kotak persegi panjang dalam diagram Venn dan ilmu matematika dipahami sebagai semesta atau area tak berbatas bisa dikatakan sebagai dunia dan alam semesta dalam kehidupan nyata.

Klaim terhadap ruang yang berkembang menjadi penentuan terhadap teritori akan menjadi hal yang sangat dihindari karena dapat mengakibatkan terganggunya stabilitas beraktivitas dalam ruang. Saat terjadinya penentuan batas-batas teritori dalam suatu ruang oleh pihak-pihak tertentu, fungsi dan manfaat ruang akan berubah karena ada beberapa hal yang terganggu misalnya akses terhadap ruang tersebut. Karena suatu ruang memiliki hubungan dengan ruang yang lain dan merupakan penentu keberhasilan suatu sistem aktivitas. Dengan demikian gangguan terhadap salah satu ruang yang berada di dalam jaringan ruang akan mengakibatkan terganggunya penggunaan jaringan tersebut. Akibatnya sistem aktivitas yang melibatkan jaringan ruang tersebut akan terganggu.

\subsubsection{Spirit of Place dari Ruang Bermukim}

Spirit of place dimaknai sebagai karakter tempat yang terjadi oleh keadaan fisik dan non fisik dimana proses rekonstruksinya menerus dan merupakan respon kebutuhan untuk perubahan dan keberlanjutan suatu komunitas. Perubahan spirit of place dimungkinkan oleh perubahan fungsi dan kebutuhan terhadap tempat tersebut oleh komunitas yang ada di dalamnya. Christian Norberg-Schulz (1980) berpendapat bahwa Spirit of Place atau Genius Loci merupakan ciri- ciri khas dari suatu tempat yang sudah dikenal orang sejak lama yang membedakan tempat tersebut dengan tempat-tempat lainnya. Spirit of Place memberikan jiwa setempat pada tempat-tempat tersebut dan mengakibatkan manusia yang berada di tempat tersebut merasa utuh karena bisa merasakan dan mengalami. Garnham (1985) memberikan arahan bahwa Spirit of Place merupakan kekuatan non fisik dan fisik yang mampu membentuk kesan dalam kota. Spirit of Place tersebut dapat timbul oleh atribut-atribut yang berdasar pada aspek-aspek lingkungan alamiah dan buatan termasuk di dalamnya adalah eksplorasi budaya, wujud-wujud akibat sejarah sosial dan tempat seprti artefak budaya serta pengalaman batin/visualisasi yang diakibatkan oleh interaksi antara budaya dan bentang alam dalam berbagai aktifitas manusia termasuk dalam aktifitas bermukim.

Proses bertempat tinggal atau bermukim adalah proses keterkaitan manusia dengan lingkungannya, dimana bermukim atau menghuni adalah kegiatan berpijak dimana manusia dapat mengorientasikan dirinya sendirinya, dapat mengidentifikasikan dirinya dengan lingkungan, dimana tempat (locus) menjadi sesuatu yang lebih dari sekedar naungan (shelter) dan dimana hal ini dipadukan. Bermukim menghadirkan kegiatan arsitektur yang berwawasan tehadap alam dimana tapak berada, dari proses kegiatan bermukim dapat dilihat proses keterkaitan dari masa lalu hingga masa kini dalam sebuah tapak. Orientasi berhubungan secara langsung dengan 3 hal atau elemen dari ruang eksistensial yakni pusat (centers), jalan (paths), dan lingkup (domains).

Rumah adalah lingkup ruang komunitas terkecil yang mencerminkan budaya penghuninya, suatu keadaan sosial dapat mempengaruhi dari tatanan rumah yang dibangun. Dikarenakan adanya pembedaan dari fungsi rumah menurut kebiasaan dalam kehidupan sehari-hari, tujuan dari rumah sendiri menghasilkan suatu pattern lebih kompleks dari pada bangunan publik. 
Konsep bermukim ini sangat cocok dengan teori Genius Loci atau Jiwa Tempat atau Spirit of the Place. Arsitektur tidak terlepas dari tempat yang bermula dari ruang. Manusia menempati 'ruang' (space), ruang-ruang dimana terjadi kehidupan akan berubah menjadi 'tempat' (place). Setiap tempat berbeda dengan tempat lainnya. Kegiatan manusia dalam berkehidupan dalam sebuah tempat membentuk karakter, identitas, sehingga dapat dikatakan setiap tempat memiliki keunikan, memiliki jiwa. Interaksi antara manusia dengan tempat hidupnya memberikan pengaruh timbal balik terhadap karakter tempat tersebut, sehingga tempat itu menjadi bermakna (meaningful place). Seharusnya konsep bermukim ini menjadi patokan para stake holder dalam mengambil keputusan dalam mengembangkan suatu kawasan baru atau pun intervensi terhadap kawasan lama, sehingga setiap ruang kota, ruang komunal, dan ruangruang publik lainnya selalu memiliki jiwa yang berbeda yang mencerminkan keagungan budaya, geografis, iklim dan konteks masyarakat setempat. Sehingga setiap penjuru ruang kota akan memberikan makna dan kesan tersendiri, tidak terjadi universalisasi dan standarilisasi yang selalu sama dan monoton.

\subsubsection{Memaknai "Image of the City" dalam Ruang Publik}

Dalam teori ini, Kevin Lynch mencoba membahas karya arsitektural dalam skala kawasan atau kota (cityscape). Lynch menerapkan pada acara-cara bagaimana kita dapat membaca atau membangun sebuah citra kawasan atau kota. Dalam mengidentifikasi suatu kawasan atau kota, Lynch menunjukkan beberapa elemen (berasal dari kepekaan panca indera) yang dapat digunakan yaitu: sensasi visual warna, bentuk, gerakan, dan cahaya, serta bau, suara, dan sentuhan. Lima elemen pembentuk citra (image) kota menurut Lynch, yaitu:

- Paths

Paths merupakan elemen linier yang biasa berpotensi digunakan untuk bergerak dan berpindah, misalnya jalan raya, jalan setapak, jalur transit, kanal, dan rel kereta api. Beberapa orang mengamati kotanya pada saat sedang berjalan atau berkendara, sehingga paths memiliki peranan penting seolah menjadi elemen utama dalam membentuk image (citra) kota. Identitas paths dapat terbentuk karena:

1. Adanya kegiatan atau fungsi tertentu sepanjang paths,

2. Karakter khusus pada paths

3. Adanya fasad dengan karakter tertentu sepanjang paths

4. Memiliki kedekatan dengan suatu fitur penting kota

Paths harus mudah diidentifikasi, memiliki arah dan tujuan yang jelas sehingga membantu pengamat dalam membentuk image kota.

- Edges

Edges menjadi pembatas antara dua daerah dan juga bisa menjadi pembatas di antara dua daerah juga penghubung yang menyatukan dua daerah. Edges bukan merupakan elemen yang dominan seperti paths, namun memgang peranan dalam membentuk suatu area atau menjadi outline suatu daerah.

- Districts

Districts merupakan bagian dari kota yang mengandung makna serta karakter tertentu. District juga merupakan bagian kota yang dominan seperti paths, karena beberapa orang membangun struktur kota melalui pengamatan terhadap district. Karakter fisik yang dapat digunakan sebagai identitas district misalnya: tekstur, bentuk, detail, symbol, bangunan dengan style tertentu, fungsi atau kegiatan tertentu, topografi, dan kegiatan masyarakat lokal pada district. Pada beberapa area yang pembangunannya terbatas, homogenitas fasad dari segi material, modelling, ornament, warna, skyline, dapat digunakan sebagai penentu identitas. Pada daerah tertentu, karakter district terbentuk karena homogenitas arsitektural serta latar belakang sejarahnya. 


\section{- Nodes}

Nodes merupakan titik/spot strategis pada kota yang dapat diakses oleh pengamat sebagai fokus dalam menentukan awal dan akhir perjalanan mereka. Nodes dapat berupa titik persimpangan, tempat pemberhentian kendaraan, dan simpul paths/jalur/jalan. Nodes dapat juga berupa pusat yang bermakna atau menjadi penting karena memiliki karakter fisik tertentu. Konsep nodes berhubungan dengan paths, karena nodes merupakan pusat atau simpang dari beberapa paths.

- Landmarks

Landmark merupakan sutau titik/spot namun tidak dapat diakses oleh pengamat atau bersifat eksternal, serta memiliki dampak yang luas dalam membentuk image kota. Beberapa landmark dapat dilihat dari berbagai sudut/jarak kota dan sebagai penanda dari suatu arah yang konstan. Benda yang bergerak secara teratur juga dapat menjadi landmark.

Elemen-elemen tersebut merupakan material dasar pembentuk image kota menurut Lynch. Elemen tersebut tidak dapat berdiri sendiri, melainkan harus disusun bersama untuk menciptakan suatu pola tata kota.

\section{A. $\quad$ Metode Penelitian}

Penelitian dilakukan di Kawasan Taman Kencana yang merupakan salah satu pusat wisata kuliner di Kota Bogor. Waktu penelitian mempertimbangkan faktor hari aktif para aktor berdatangan ke kawasan ini, termasuk kondisi khusus terkait kultur dan event-event tertentu. Aktor-aktor yang beraktifitas di kawasan Taman Kencana ini terbagi menjadi empat, yakni: penghuni rumah-rumah di kawasan Taman Kencana, pengunjung kawasan Taman Kencana, penjual komoditi di kawasan Taman Kencana (bisa saja sekaligus penghuni), aktor penunjang (parkir, park ranger, petugas kebersihan).

Alokasi waktu untuk pengamatan dibagi berdasarkan rentang waktu dan dibagi menjadi dua kategori besar. Saat hari kerja dan saat hari libur. Dasar pembagian kategori ini ialah, adanya perbedaan daur hidup pelaku aktivitas pada masing - masing kategori sehingga berpengaruh pada perubahan atas dampak perkembangan Kawasan Taman Kencana ini. Waktu pengamatan akan kembali dipecah berdasarkan rentang waktu pagi - siang - sore - dan malam hari. Issue utama adalah dampak dari perkembangan Kawasan Taman Kencana.

Untuk menilik fenomena ini, peneliti perlu mengungkap data secara kualitatif. Pengumpulan data di mulai dengan mengidentifikasi perubahan struktur ruang kota melalui pendekatan riset arsip. Dalam hal ini riset arsip yang dimaksud adalah pendekatan yang berdasar pada fakta tertulis (dokumen) atau berupa arsip data. Data ini kemudian akan digunakan peneliti untuk mengungkap pola perubahan struktur ruang kota yang menjadi dasar titik awal perkembangan kawasan ini. Untuk memahami dampak apa yang dirasakan oleh masyarakat sebagai aktor dalam kawasan tersebut, peneliti perlu melakukan wawancara dan pengamatan secara berkala. Hasil dari pengamatan lapangan akan dibandingkan dengan hasil dari riset arsip sehingga dapat membantu peneliti mengungkap perubahan atas dampak perkembangan kawasan Taman Kencana ini.

\section{Hasil dan Diskusi}

Kawasan Taman Kencana kini telah menjadi salah satu tujuan wisata kuliner favorit di Bogor. Keadaan ini dipandang sebagai sebuah potensi ekonomi yang menggiurkan. Satupersatu bangunan peninggalan masa pemerintahan Belanda disulap menjadi sebuah kedai makanan atau cafe yang menarik untuk dikunjungi. Tanah kosong pun dibangun lapak-lapak yang setiap bulannya mendatangkan uang sewa. Semakin ramai pengunjung, semakin banyak 
kendaraan berlalu lalang dan berhenti. Hal ini pun menjadi salah satu potensi, yakni parkir. Banyak juga pedagang kaki lima yang singgah karena banyaknya pengunjung yang datang. Semakin banyak manusia yang bergerak di kawasan ini, makin banyak pula perputaran uang terjadi. Aktivitas di lapak atau kedai makanan, parkir, jajanan kecil di pinggiran jalan, hingga menjadi salah satu tempat transit angkutan umum menjadi potensi perkembangan ekonomi yang perlahan merubah citra dari kawasan ini.

Perkembangan kawasan Taman Kencana tersebut tentu saja berdampak pada beberapa hal terkait aktor yang berkegiatan di kawasan ini. Dampak tersebut pun dinilai akan menjadi sebuah penilaian subjektif tergantung sudut pandang aktor-aktornya. Aktor-aktor yang beraktifitas di kawasan Taman Kencana ini terbagi menjadi empat, yakni:

1. Penghuni rumah-rumah di kawasan Taman Kencana

2. Pengunjung kawasan Taman Kencana

3. Penjual Komoditi di kawasan Taman Kencana (bisa saja sekaligus penghuni)

4. Aktor penunjang (parkir, park ranger, petugas kebersihan)

Aktor-aktor tersebut dikelompokkan supaya dapat dilihat perubahan kawasan Taman Kencana dalam mengakomodir aktifitas penggunanya. Hal tersebut dapat terlihat dengan melakukan analisis path, edges, dan district dari kawasan Taman Kencana ini.

\subsection{Path}

\section{Tabel 1: Analisis Path}

\begin{tabular}{|c|c|}
\hline Path & Analisis Path \\
\hline $\begin{array}{l}\text { Jl. Taman } \\
\text { Kencana }\end{array}$ & $\begin{array}{l}\text { Lebar Jalan sekitar enam meter yang } \\
\text { dibatasi oleh adanya jalur hijau. } \\
\text { Karena Jalan Taman Kencana bukan } \\
\text { merupakan jalur utama (jalan } \\
\text { arteri) kota, pada Hari Minggu Jalan } \\
\text { Taman Kencana dimanfaatkan } \\
\text { untuk tempat parkir bagi } \\
\text { pengunjung Taman Kencana dan }\end{array}$ \\
\hline Jl. Salak & 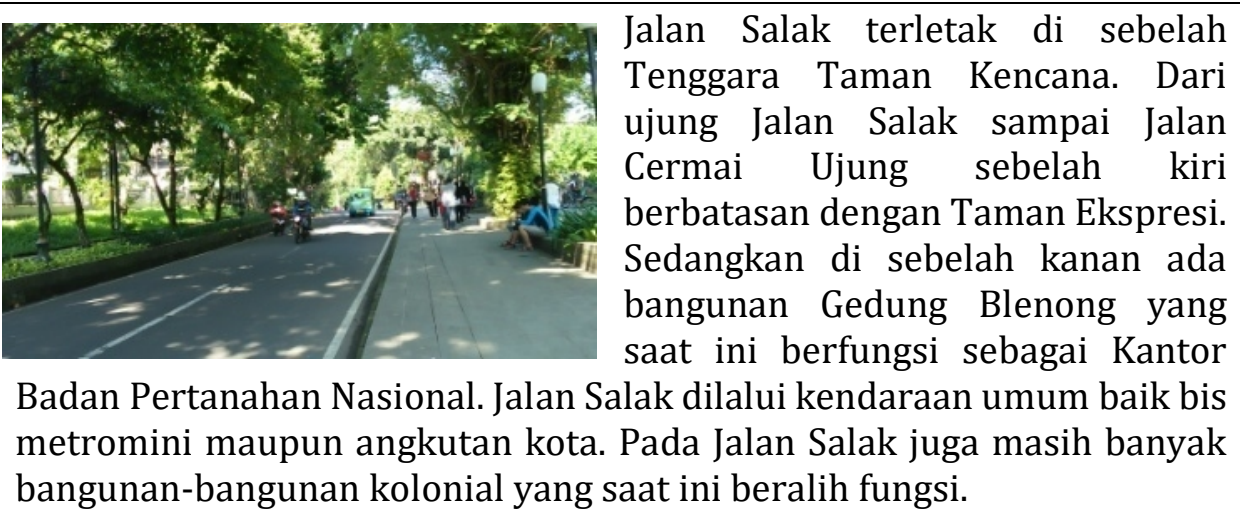 \\
\hline
\end{tabular}




\begin{tabular}{|c|c|}
\hline $\begin{array}{l}\text { Il. Cir } \\
\text { Ujung }\end{array}$ & $\begin{array}{l}\text { Jalan Ciremai Ujung terletak di } \\
\text { sebelah Barat Daya dari Taman } \\
\text { Kencana. Lebar Jalan enam meter } \\
\text { yang dibatasi tempat parkir dimana } \\
\text { di Jalan Ciremai ujung ini terdapat } \\
\text { kios-kios kuliner seperti warung } \\
\text { taman dan beberapa warung } \\
\text { lainnya. Pada Hari Minggu parkir di }\end{array}$ \\
\hline Jl. Pangrango & 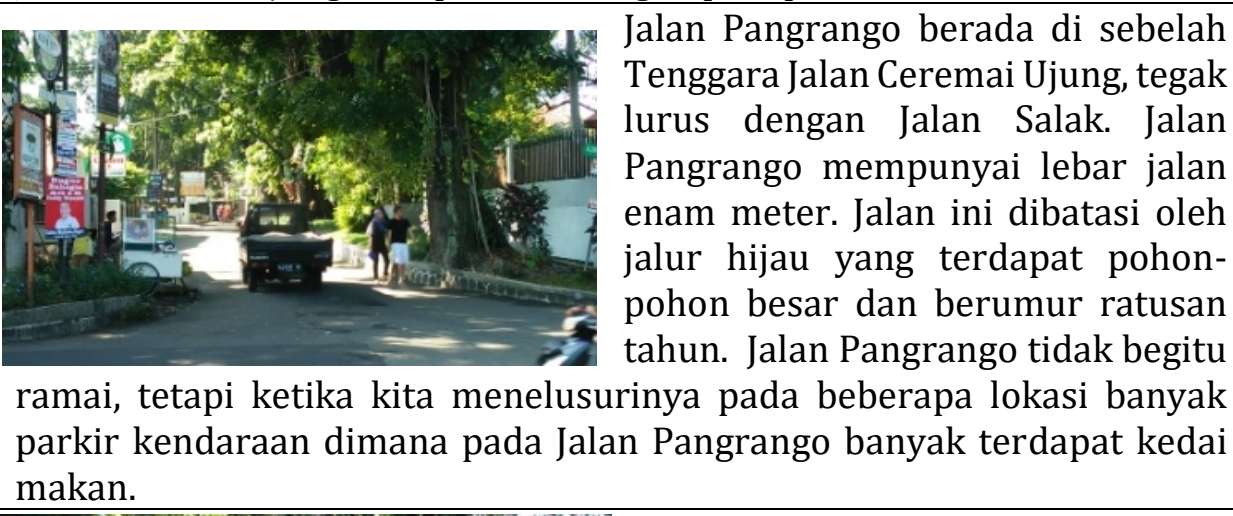 \\
\hline & 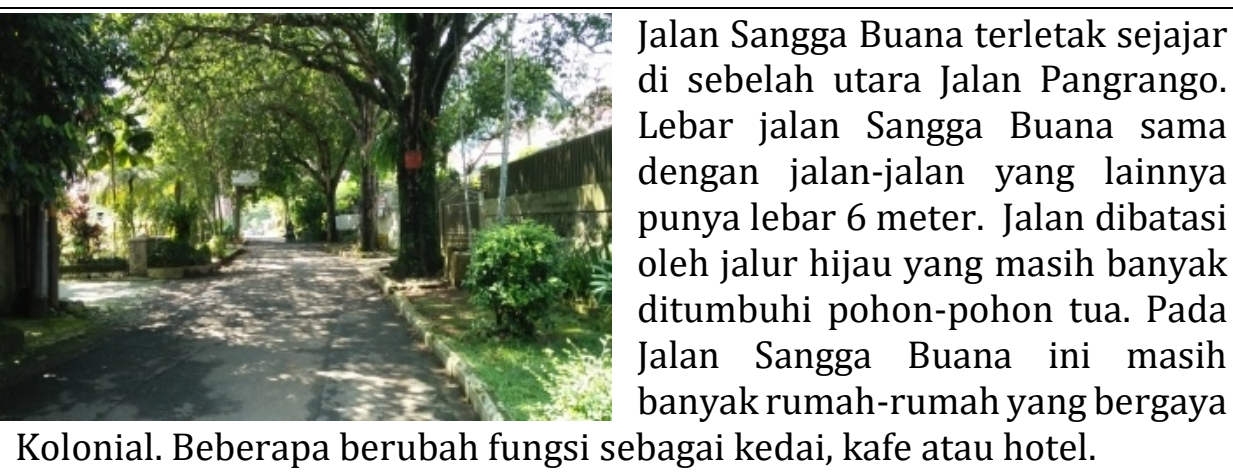 \\
\hline $\begin{array}{l}\text { Il. Tangkuban } \\
\text { Perahu }\end{array}$ & $\begin{array}{ll}\text { rumah. } & \begin{array}{l}\text { Jalan Tangkuban Perahu berada } \\
\text { diantara Gedung Pusat Studi } \\
\text { Biofarma dan Pusat Penelitian } \\
\text { Bioteknologi dan Bioindustri } \\
\text { Indonesia. Jalan tangkuban Perahu } \\
\text { seperti jalan lain di sekitar Taman } \\
\text { Kencana mempunyai lebar } 6 \text { meter, } \\
\text { dibatasi jalur hijau baru batas }\end{array} \\
\text { ruman } & \end{array}$ \\
\hline
\end{tabular}




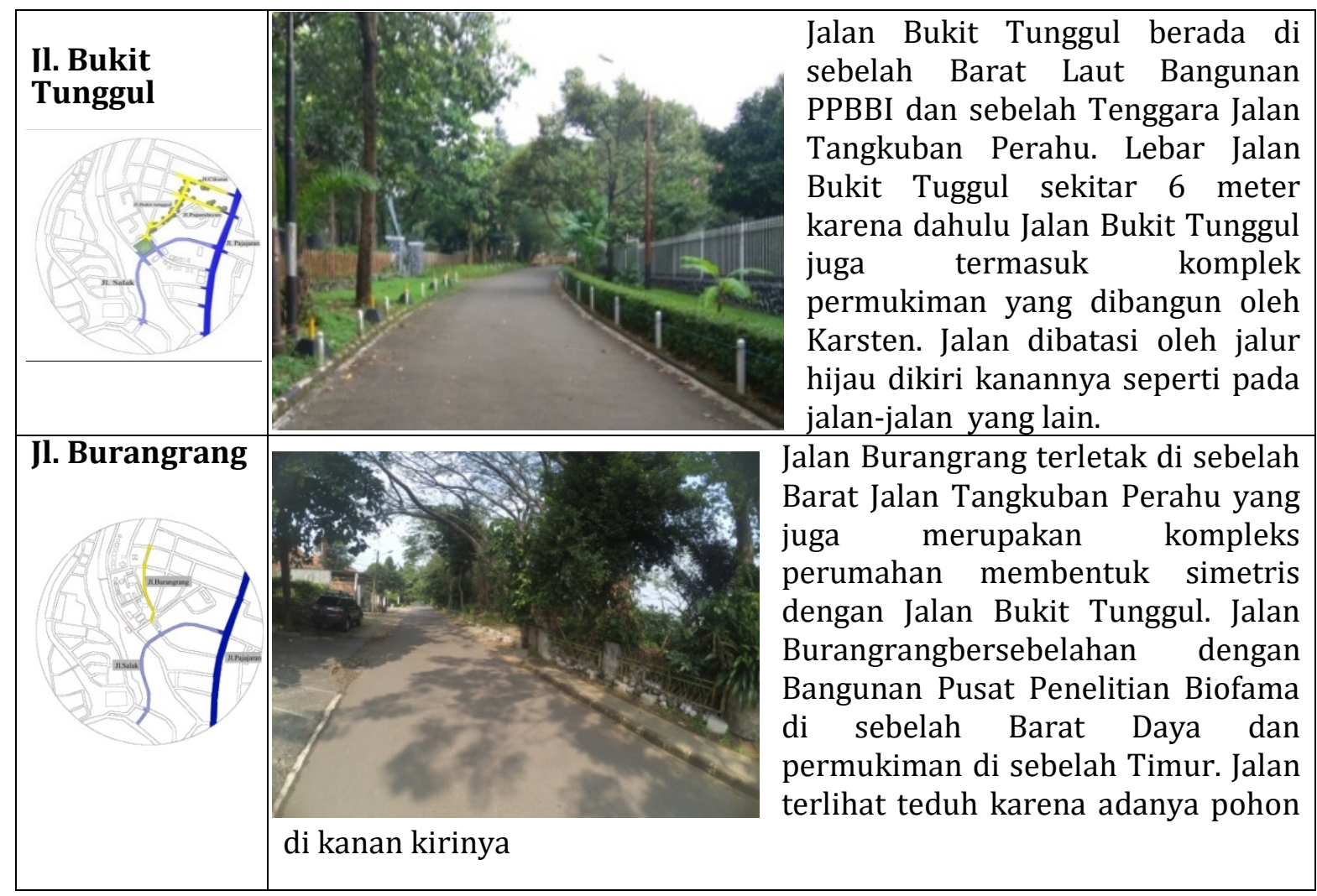

\subsection{Edges}

Tabel 2. Analisis Edges

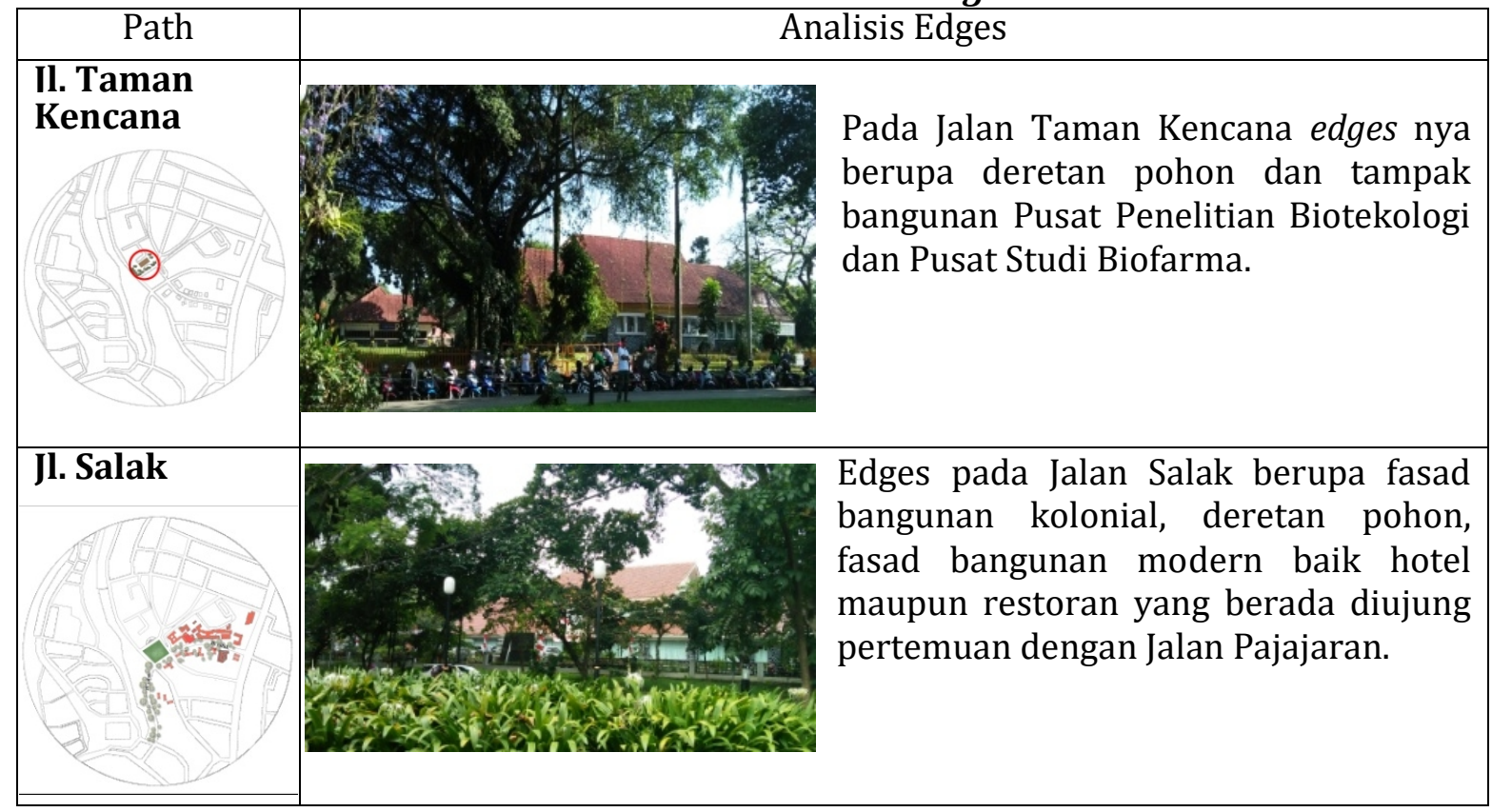




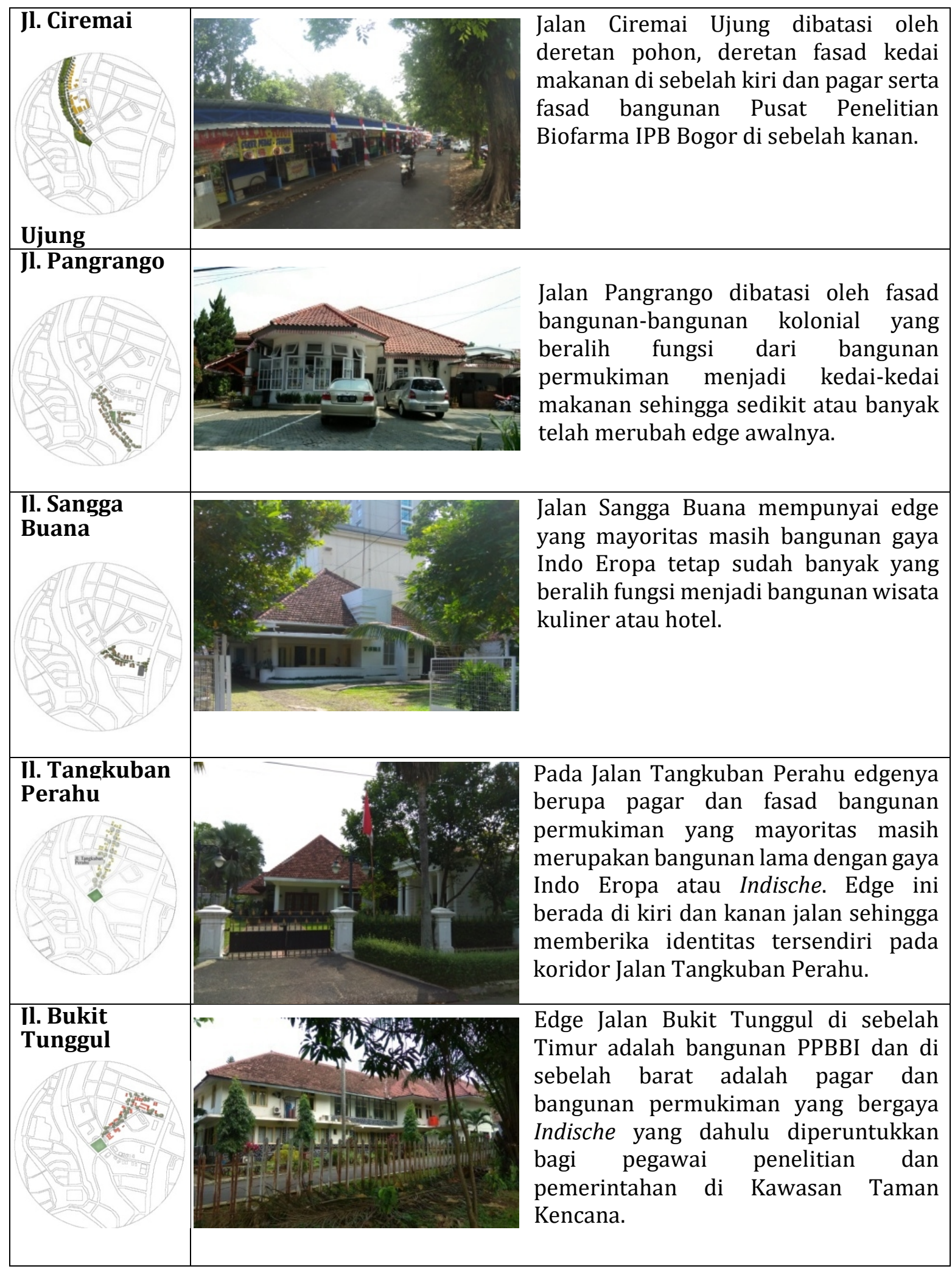




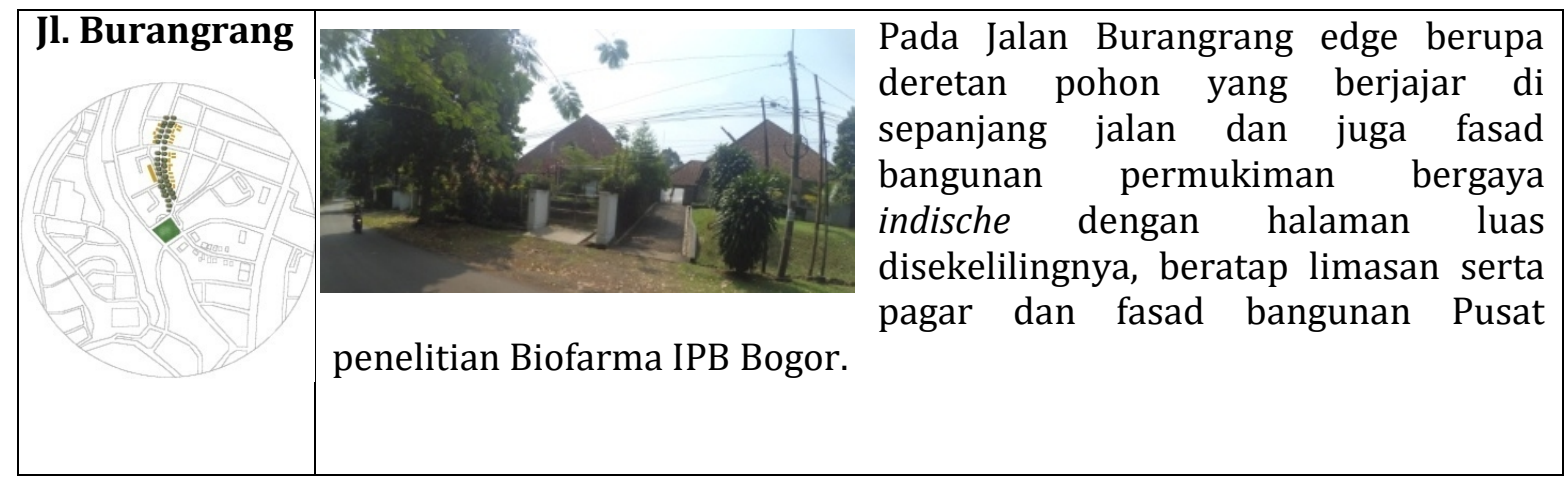

\subsection{District}

Tabel 3. Analisis Distrik Kawasan Taman Kencana

\begin{tabular}{|l|l|}
\hline \multicolumn{1}{|c|}{ Distrik Permukiman } & \multicolumn{1}{|c|}{ Distrik Perdagangan } \\
\hline \multicolumn{3}{|c|}{$\begin{array}{l}\text { Kencana yang saat ini telah mengalami } \\
\text { beberapa kecenderungan perubahan } \\
\text { menjadi distrik wisata kuliner. }\end{array}$} & $\begin{array}{l}\text { Kencana sebagai distrik permukiman } \\
\text { bangunan kolonial Indische dengan Koridor } \\
\text { Pajajaran yang merupakan distrik } \\
\text { perdagangan }\end{array}$ \\
\hline
\end{tabular}

Dari analisis di atas dapat terlihat path-path yang ada di kawasan Taman Kencana mengalami banyak perubahan. Path yang tadinya berupa jalan lingkungan perumahan berubah menjadi jalan yang dilalui oleh publik. Keadaan ini pun mengindikasikan perkembangan kawasan Taman Kencana tak luput dari dampak negatif. Terdapat penurunan kualitas lingkungan seperti jalan rusak dan berlubang, kawasan ini pun tak lagi tenang, serta terjadi penurunan tingkat keamanan karena pengunjung yang datang tidak dapat terkontrol asalnya darimana sehingga mengundang tindakan kriminal yang mengancam distrik di kawasan ini.

Dampak dari perkembangan kawasan Taman Kencana ini menggambarkan adanya benturan klaim terhadap sebuah ruang, yang dimaknai sebagai sebuah klaim negatif karena merugikan pihak lain. Pengguna jalan (pengunjung, penjual dan aktor penunjang) dalam mengambil keuntungan dari perkembangan kawasan ini merugikan pihak penghuni dengan mengganggu ketenangan serta menurunkan kualitas lingkungan permukimannnya.

Penghuni pun saat ini tidak tinggal diam dan menunjukan tindakan aksi-reaksi terhadap klaim negatif ini yakni berupa banyaknya digunakan portal di sebagian jalan sebagai bentuk proteksi agar tidak semua jalan mengalami penurunan kualitas akibat dampak dari ramainya pengunjung kawasan Taman Kencana ini. 


\section{Simpulan}

Perkembangan kawasan Taman Kencana ini memberikan dampak positif maupun dampak negatif secara bersamaan. Perputaran uang yang cepat tentu saja menjadi potensi ekonomi dari kawasan ini, namun juga memberikan dampak negatif berupa perununan kualitas lingkungan sebagai kawasan permukiman yang awalnya tenang dan nyaman. Keadaan ini pun mengindikasikan adanya hubungan tarik-menarik kepentingan antara fungsi kawasan sebagai kawasan permukiman dan kawasan wisata kuliner, dan terjadilah benturan klaim akan ruang.

\section{Ucapan Terima kasih}

Dari hasil penelitian ini, dapat dilihat dampak dari perubahan dan perkembangan suatu kawasan. Sebaiknya, pemerintah dan para pemangku kepentingan dapat mempertimbangkan hal ini dalam mengatur kebijakan terkait fungsi sebuah kawasan. Kami sebagai tim peneliti mengucapkan terima kasih kepada seluruh pihak yang membantu proses penelitian dan penulisan jurnal ini hingga selesai.

\section{Daftar Pustaka}

Alsayyad, Nezar. (2001). Consuming Tradition, Manufacturing Heritage, Global Norms and Urban Forms in the Age of Tourism. New York: Rouledge.

Ardyanto. ( - ). Taman Kencana - bukan hanya sekedar kuliner. http://lovelybogor.com/ taman-kencana-bogor/ diakses tanggal 20 Mei 2016

Arendt, Hannah. (1958). The Human Condition, $2^{\text {nd }}$ ed. Chicago: University of Chicago Press.

Carmona, Matthew, T. Heath, T. Oc, dan S. Tiesdel, et al. (2003). Public Places, Urban Spaces. Oxford dan Burlington: Architectural Press.

Daimtri \& Jokoprast. (2014). Persepsi Ruang Perkotaan (1). http://itscomma9.com/persepsiterhadap-ruang-perkotaan-1/ diakses tanggal 15 Mei 2016

Daimtri, (2014). Persepsi Ruang Perkotaan (2). http://itscomma9.com/persepsi-terhadapruang-perkotaan-2/ diakses tanggal 15 Mei 2016

Gedebudi. (2008). Kontribusi Thomas Karsten Bagi Perencanaan Kota Di Indonesia, Refleksi Bagi Perencana Kota. diakses tanggal 20 Mei 2016

Heryanto, Bambang. 2011. Roh dan Citra Kota. Surabaya: Brillian Internasional

Hillier, Bill. (2007). Space is The Machine: Space Syntax. London: Press Syndicate of University of Cambridge

Jacobs, Jane M. (2004). dalam Nezar Alsayyad, The End of Tradition. New York: Rouledge.

Laurens, Joyce Marcella. (2005). Arsitektur dan Perilaku Manusia. Jakarta. PT, Grasindo

Lynch, Kevin. (1960). The Image of the City, MIT Press, Cambridge MA

Mulyandari, H. (2011). Pengantar Arsitektur Kota. Jakarta: Andi Publisher.

Saarinen, Thomas F. (1976). Environmental Planning: Perception and Behavior. Boston. Houghton Mifflin Company

Schulz, Christian Norberg. (1979). Genius Loci, Towards a Phenomenology of Architecture. New York: Rizzoli.

Sita, Maya. (2010). Klaim Terhadap Ruang. "Studi Kasus Pada Rusun Sukaramai Medan". Depok: Universitas Indonesia.

Tuan, Yi-Fu. (1977). Space and Place, The Perspective of Experience. Mineapolis. University of Minnesota Press. 